\title{
РЕЦЕНЗІї
}

\section{УПЕРШЕ ВСЕСВІТНЬО ВІДОМА ПЕРЕКЛАДОЗНАВЧА ЕНЦИКЛОПЕДІЯ - УКРАЇНСЬКОЮ МОВОЮ}

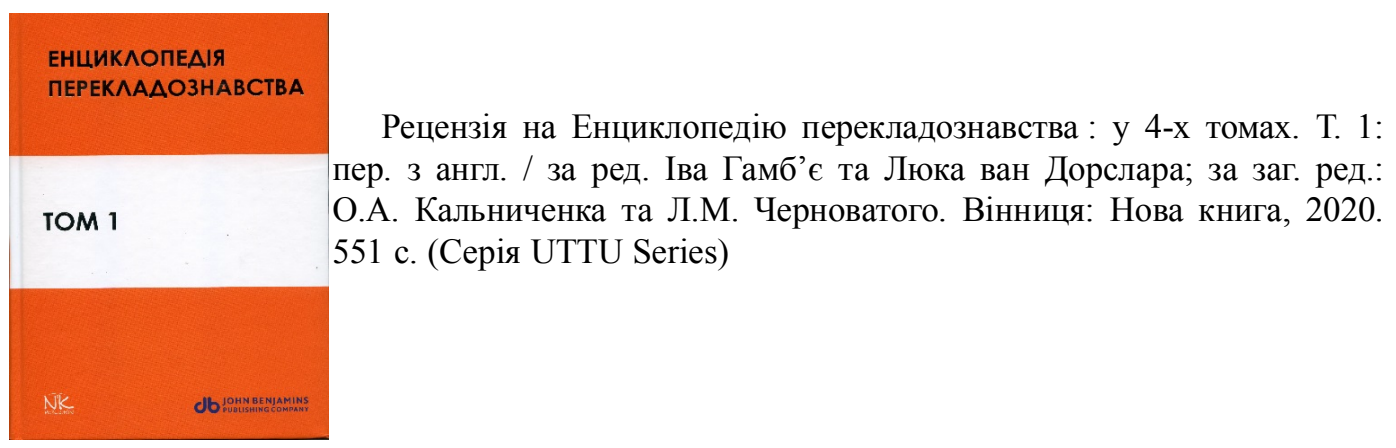

Закордонна перекладознавча література майже не перекладається у нашій країні, за винятком окремих статей в університетських виданнях, тим більше, коли йдеться про такі зазвичай великі за обсягом книги, як енциклопедії. Водночас наукові енциклопедії високого рівня як світові надбання заслуговують на переклад і таки перекладаються. Вони призначені бути справжніми скарбницями спеціальних знань і, звичайно, характеризуються великою достовірністю, перевіреністю фактів, фундаментальністю й здатністю викликати плідну дискусію, то саме через це їх слід перекладати, аби сприяти науковому розвитку в країні перекладу.

Тому слід вітати факт видання перекладу українською мовою першого, тому такого авторитетного у світі, як Handbook of Translation Studies, тим більше що в Україні були відсутні будь-які авторитетні довідкові видання з перекладознавства. Цей переклад вийшов у світ у серії під егідою та завдяки сприянню Всеукраїнської спілки викладачів перекладу як уже десяте видання.

Варто окремо зазначити значну складність цього перекладацького проєкту, оскільки, по-перше, раніше подібні масштабні проєкти у нашій країні не здійснювалися, по-друге, перекладознавча термінологія англійською мовою розвинена значно більше, ніж українською, тому природно, що немало українських відповідників англійських термінів, особливо відносно нових, відсутні, та, по-третє, українська перекладознавча термінологія досі ще недостатньо уніфікована і стандартизована, зокрема й через відсутність тлумачних або перекладних термінологічних словників.

На теперішній час у світі зроблено 344 переклади статей цієї чотиритомної енциклопедії, представлених в онлайні тринадцятьма мовами (Statistics). Найбільше перекладів статей виконано українською мовою (120 статей (тобто, перекладено весь перший том видання та частина статей з інших томів), і значно менше (88 статей) французькою мовою, тому можна стверджувати, що українські перекладознавці встановили своєрідний рекорд з перекладу цієї енциклопедії.

Видання перекладознавчої енциклопедії, хоч і у перекладі, становить важливу віху у закріпленні в країні статусу науки, у нашому випадку перекладознавства. Таке видання стимулює перекладознавців до подальшого розвитку привертає увагу наукової молоді, сприяє уніфікації та стандартизації перекладознавчої термінології, активізує написання та публікацію наукових статей, навчальних посібників, підручників і довідників та заохочує заклади вищої 
освіти, де викладається та досліджується переклад, до проведення наукових дискусій і конференцій. До речі, галузеві енциклопедії та довідники - це саме ті видання, які повинні мати у своїй бібліотеці професіонали з певної галузі.

Серед авторів рецензованого першого тому такі відомі у світі дослідники перекладу, як Ампаро Уртадо Альбір, Фабіу Альвес, Мері Снел-Горнбі, Ів Гамб’є, Даніель Гуадек, Люк ван Дорслар, Дороті Келлі, Сара Лавіоза, Маріанн Ледерер, Кірстен Малмк'єр, Джеремі Мандей, Крістіана Норд, МевОлоган, Алешандра Асіш Роза, Луїз фон Флотов, Дебора Цао, Крістіна Шефнер та інші.

У 74-х статтях енциклопедії представлено найважливіші грані перекладознавства ключові елементи його концептуального та термінологічного апарату (“переклад”, “адаптація”, “автопереклад”, “перекладознавство”, “трансфер” тощо), розділи й підрозділи перекладознавства (історія перекладу, машинний переклад, прикладне перекладознавство тощо), теорії та моделі перекладу (усного, аудіовізуального, письмового тощо), підходи до дослідження перекладу (дескриптивний, прикладний, інтерпретативний, когнітивний, етнографічний, функціональний тощо); аспекти перекладу (релевантність, норми, одиниці, стратегії, множинність, відкритість і закритість тощо), зв'язки перекладу з іншими, переважно суміжними науками, зокрема, такими, як літературознавство, семіотика, термінознавство, герменевтика, етика, журналістика, соціологія тощо, методи перекладознавчого дослідження (корпусні, експериментальні тощо), особливості перекладу текстів різних жанрів, типи й види перекладу (письмовий та усний переклад, комп'ютерний переклад, галузевий переклад тощо), питання застосування інформаційних технологій у перекладі; нетворкінг і діяльність перекладачів-волонтерів; зміст і структура процесу перекладу та інструменти його дослідження, якість перекладу і класифікація перекладацьких помилок, проблеми методики навчання перекладу тощо.

У цілому рецензоване видання характеризується високою інформаційною насиченістю, відповідністю потребам поширення знань про переклад і перекладознавство та розвитку науки про переклад взагалі. Обсяг публікації доволі великий - 45,67 ум. друк. арк., іiї поліграфічна якість на достатньому рівні: тверда палітурка з чітким дизайном, офсетний папір й офсетний друк. Перекладена енциклопедія частково компенсує певний брак якісної довідкової українськомовної літератури з перекладознавства (у таких ситуаціях лакуни в національній науковій літературі зазвичай заповнюються перекладною літературою) та забезпечує доступ студентів, аспірантів і викладачів перекладу (які за межами провідних перекладознавчих центрів не мають достатньо глибоких знань 3 перекладознавства) до доволі систематизованого джерела західних теорій, поглядів танаукових тлумачень. Вона дає змогу критично аналізувати висловлені міркування перекладознавців як у межах лекцій і семінарів, так і в наукових публікаціях і формувати власні підходи до вирішення відповідних проблем; вона дає змогу розпочати обговорення проблем української перекладознавчої термінології, які чітко проявляються в перекладах різних статей енциклопедії і має підштовхнути українських перекладознавців до створення власної довідкової літератури, яка б враховувала і світовий, і національний досвід.

Щодо перекладу першого тому енциклопедії $є$ кілька побажань, які мають на меті поліпшення якості в разі перекладу наступних томів енциклопедії та можливого перевидання першого тому. Як нам видається, зовсім не зайвими були б в українському виданні енциклопедії предметний та іменний покажчики, що суттєво допомогло б читачеві орієнтуватися в об'ємному (довідковому!) томі та швидко знаходити потрібну інформацію.

У бібліографічному опису анотації книги на сторінці вихідних даних ім'я та прізвище одного із співредакторів книги помилково зазначені як Івз Гамбіер (в оригіналі Yves Gambier), тоді як у статті на С. 310 та в самій анотації довідника дано правильне транскодування - Ів Гамб’.

У деяких статтях в їхніх назвах наявні два варіанти перекладу терміна, що неприпустимо у друкованому виданні, де переклад має подаватися без варіантів. Наприклад, у перекладі 
назви статті "Descriptive Translation Studies" $є$ другий варіант перекладу терміна descriptive “дескриптивне (описове) перекладознавство” (С. 77), хоча термін “дескриптивний” в українській мові вже доволі усталений. У перекладі назви статті “Transfer and Transfer Studies” (С. 332) як “перенос (трансфер) та трансферні студії” також наведено другий варіант перекладу першого у назві терміна, хоча зазначений етап процесу перекладу звичайно позначається в українській мові терміном “трансфер”.

Переклад назви статті “Community Interpreting” також подано 3 двома варіантами перекладу слова "community" - "Усний переклад для потреб громади / Усний переклад у соціальній сфері" (С. 503). Тут перекладачу слід було б зупинитися на останньому варіанті як наразі вже значно частотнішому. Зайвим у перекладі назви статті “Consecutive Interpreting” видається використання слова “усний”- "Послідовний усний переклад” (С. 363), оскільки наявність терміна “послідовний” вже передбачає, що йдеться про усний переклад.

Термін "technical translation" у назві статті неправильно перекладений як “технічний переклад” (С. 486) - потрібно “Спеціалізований / спеціальний переклад”. Це типова помилка ще $з$ тих часів, коли термін "technicalaid" став перекладатися як “технічна допомога" (правильно - "спеціальна / спеціалізована допомога" (консультація тощо), адже сам перекладач вживає у перекладі статті термін "моделі спеціалізованої комунікації” (С. 486).

На С. 200 англійський термін у множині соrрora перекладено українським відповідником в однині “корпус" (правильніше було б “корпуси текстів"). Термін computer-aided translation слід, на наш погляд, перекладати не як “автоматизований переклад” (С. 10, 163, 215 та ін.), а “переклад за допомогою (комп’ютерних) апаратно-програмних засобів”.

Помилковим є транскодування деяких власних імен авторів статей, наприклад на С. 127 ірландське ім'я Siobhan слід передавати українською як Шивон, а не як Сьобган, на С. 17 ім'я Chiara помилково подано з м'яким знаком (Кьяра) натомість правильного написання українською мовою К'яра, а на С. 343 у прізвищі одного із співавторів статті не надруковано останню літеру - Коскінен подано Коскіне, а ім'я другого співавтора транскодовано неправильно як Оуті, а не як потрібно - Уті. На С. 392 ім'я та прізвище автора статті подано неправильно Рітта Яааскелайнен натомість Рійтта Яаскеляйнен, на С. 403 ім'я та прізвище одного вченого подано разом - ФабіуАлвес (до речі на С. 153 знаходимо вже Фабіо Альвес), і таке ж написання разом зустрічається на С. 332 у зазначенні перекладача статті - Andrii Kozachuk.

У перекладах спостерігається інтерфероване (з російської мови) вживання прийменника “при” у сполученні з наступним іменником на кшталт “При вивченні політичного перекладу..." (С. 357) та “...що може відбуватися при перекладі...” (С. 196). В українському мовленні у таких випадках вживаються прийменники “для”, “під час", “у разі” або дієприкметниковий зворот: У разі вивчення..., Вивчаючи...; “....що може відбуватися під час ...”.

Слід було б навести пояснення значення рідкого терміна "канібалістський переклад", вжитого на С. 357 (в англійській мові - "cannibalistic translation" - це переклад, який пориває зв'язок з оригіналом та стає нібито головним текстом унаслідок дій “деміурга”-перекладача) (Guldin).

У деяких випадках у перекладі (наприклад, на С. 198) спостерігається типова інтерференційна помилка в перекладі англійського прикметника linguistic у сполученні з іменниками (у цьому разі з “data"), який має два значення -"related to language" та "related to linguistics", але у першому значенні його слід перекладати (стосовно мовних елементів тощо) не як “лінгвістичні дані”, а як “мовні дані”, а у другому значенні - як “лінгвістичний” (наприклад, вісник або університет).

Попри викладені вище зауваження, рецензований перший том “Енциклопедії перекладознавства” у перекладі українською мовою є актуальною, дуже корисною та потрібною працею, яка, безперечно, прислужиться справі розвитку науки про переклад в Україні. 
Iз нетерпінням можна очікувати появи перекладів інших трьох томів цього популярного видання, а редакторам та всім перекладознавцям слід побажати подальшого плідного співробітництва зі світовими центрами видання перекладознавчої літератури.

\section{Література}

Statistics. Retrieved from https://benjamins.com/online/hts/list/statistics.

Guldin R. Devouring the Other: cannibalism, translation and the construction of cultural identity. Retrieved from https://www.academia.edu/2111494/Devouring_the_Other_cannibalism_ translation_and_the_construction_of_cultural_identity.

Рецензент - професор кафедри теорії та практики перекладу з англійської мови Інституту філології Київського національного університету імені Тараса Шевченка, доктор філологічних наук, професор 